\title{
Nuorten kivikkoinen tie vakaalle työuralle
}

Nuorten opiskelu- ja työurat tutkimuksen ${ }^{1}$ kohteena

Hannu Koponen

\begin{abstract}
Nuorten opiskelussa ja työllisyydessä tapahtui selkeitä muutoksia 1990-luvulla. Vuosikymmenen vaihteen nousukausi muuttui lamaksi ja nuorisotyöttömyys nousi jyrkästi vuoteen 1993, mistä se pikku hiljaa aleni. Vastaavasti opiskelu yleistyi huomattavasti. Nousukauden vakaiden työsuhteiden sijaan nuorten työurat olivat vuosikymmenen lopullakin epävakaampia ja ammattitutkinnon suorittamisen jälkeinen opintojen jatkaminen huomattavan yleistä. Miten nuoret tässä tilanteessa tulivat työelämään ja mitkä tekijät vaikuttivat heidän menestykseensä työmarkkinoilla?
\end{abstract}

Nuorten oma ratkaisu työllisyyden heikkenemiseen on ollut työllisyysmahdollisuuksien parantaminen opiskelun avulla. Nuoret opiskelevat pidempään ja enemmän kuin koskaan ennen. Vain pieni joukko nuoria on jäänyt kokonaan työ- ja opiskelu-urien ulkopuolelle. Opiskelun lisääntymistä kuvaa taulukko 1 eri nuorisoryhmien kokomuutokset (ks. myös ryhmäjaottelu viite 1).

Tutkimusryhmiä kokonaisuudessaan tarkasteltaessa havaitaan, että kaikkina seurantajaksoina 16-vuotiaista ja ylioppilastutkinnon suorittaneista ylivoimainen enemmistö jatkoi opintojaan. Ammattitutkinnon suorittaneiden opintojen jatkaminen oli myös suhteellisen yleistä ja se yleistyi vuosikymmenen kuluessa. 25-vuotiaat näyttivät ohittaneen opiskeluiän. (kuvio 1)

20- ja 25-vuotiaiden opiskeluaktiivisuus oli alhainen, vaikka heidän menestyksensä työmarkkinoilla oli joiltakin osin hyvinkin heikko. 20vuotiaista vakaalla työuralla oli vain viidesosa ja pitkäaikaistyöttömänä 20-30 prosenttia. 25-vuo- tiaista kaikkina seurantajaksoina noin $40 \%$ oli vakaasti työllistyneitä, mutta toisaalta suunnilleen saman verran oli pitkäaikaistyöttöminä tai epävakaalla työuralla. Vuosikymmenen edetessä ei 25-vuotiaiden menestys työmarkkinoilla myöskään parantunut, päinvastoin kuin 20-vuotiailla, joiden työurat paranivat hieman viimeisenä seurantajaksona. Näihin ryhmiin kuuluivat siis koulutuskielteisimmät nuoret, joiden opiskeluaktiivisuutta ei heikko työmarkkina-asemakaan lisännyt. Toisaalta peruskoulun jälkeisen opiskelun yleistyttyä erityisesti laman syvimpinä vuosina 1992-94 ja pysyttyä tämänkin jälkeen korkealla tasolla, näiden ryhmien koko pieneni noin kolmanneksella vuoden 1992 otoksesta vuoden 1996 otokseen.

Kuvion 1 mukaan ammattitutkinnon suorittaneiden asema työmarkkinoilla ei ollut sekään erityisen hyvä: laman pohjalta vähenevää pitkäaikaistyöttömyyttä korvasi lähinnä lisääntynyt opiskelu eikä vakaa työura juurikaan yleistynyt. Ryhmä on kuitenkin hyvin heterogeeninen. 
Taulukko 1. Tutkimusryhmien koot

19921996

16-vuotiaat

$5605 \quad 5483$

20 -vuotiaat, ei opiskelua.

ei tutkintoa

$930 \quad 556$

25-vuotiaat, ei opiskelua,

ei tutkintoa

$1131 \quad 820$

ylioppilaat

2090

2786

muun tutkinnon suorittaneet $4774 \quad 5097$

yhteensä

$14530 \quad 14742$

Alimpia tutkintoja (alempi keskiaste, kolmasosa ryhmästä) suorittaneet työllistyivät vakaasti huomattavasti harvemmin kuin korkeampia tutkintoja suorittaneet, eikä vakaa työura myöskään yleistynyt. Heidän pitkäaikaistyöttömyytensä väheni vuosikymmenen kuluessa, mutta oli edelleen viimeisenä seurantajaksona yli kymmenen prosenttia kun vähintään alemman kandidaattiasteen tutkinnon suorittaneista pitkäaikaistyöttömiksi joutui kahtena viimeisenä seurantajak- sona vain 1-3 prosenttia. Tutkinnon taso ja menestys työmarkkinoilla kulkevat tässäkin käsi kädessä: korkeammalla tutkinnolla pääsi parempien töiden lisäksi paremmin töihin.

Menestys työmarkkinoilla vaihteli myös tutkinnon alan mukaan (kuvio 2). Suuremmassa määrin työttömiksi valmistuttiin lähinnä vuoden 1992 otoksen ammattikoulutasoisilla tekniikan tutkinnoilla. Alimman korkea-asteen hoitoalan tutkinnon suorittaneiden pitkäaikaistyöttömyys lisääntyi vielä vuoden 1994 otoksella, muuten pitkäaikaistyöttömyys väheni kaikilla tarkastelluilla aloilla ja -tasoilla, selkeimmin eri tasoisten tekniikan ja luonnontieteen tutkinnon suorittaneilla. Vakaasti työllistyneiden osuudet olivat käänteiset pitkäaikaistyöttömien osuuteen verrattuna: tekniikan alan tutkintojen suorittaneiden asema parani eniten.

Opiskelu oli investointi tulevaisuuteen. Ja mitä korkeamman tutkinnon opiskelija suoritti, sitä tuottavampi tämä investointi oli. Alimpienkin ammatillisten tutkintojen suorittajat pärjäsivät yleisesti ottaen paremmin työmarkkinoilla

Kuvio 1. Tutkimusryhmien urat kahden vuoden seurannassa (\%).

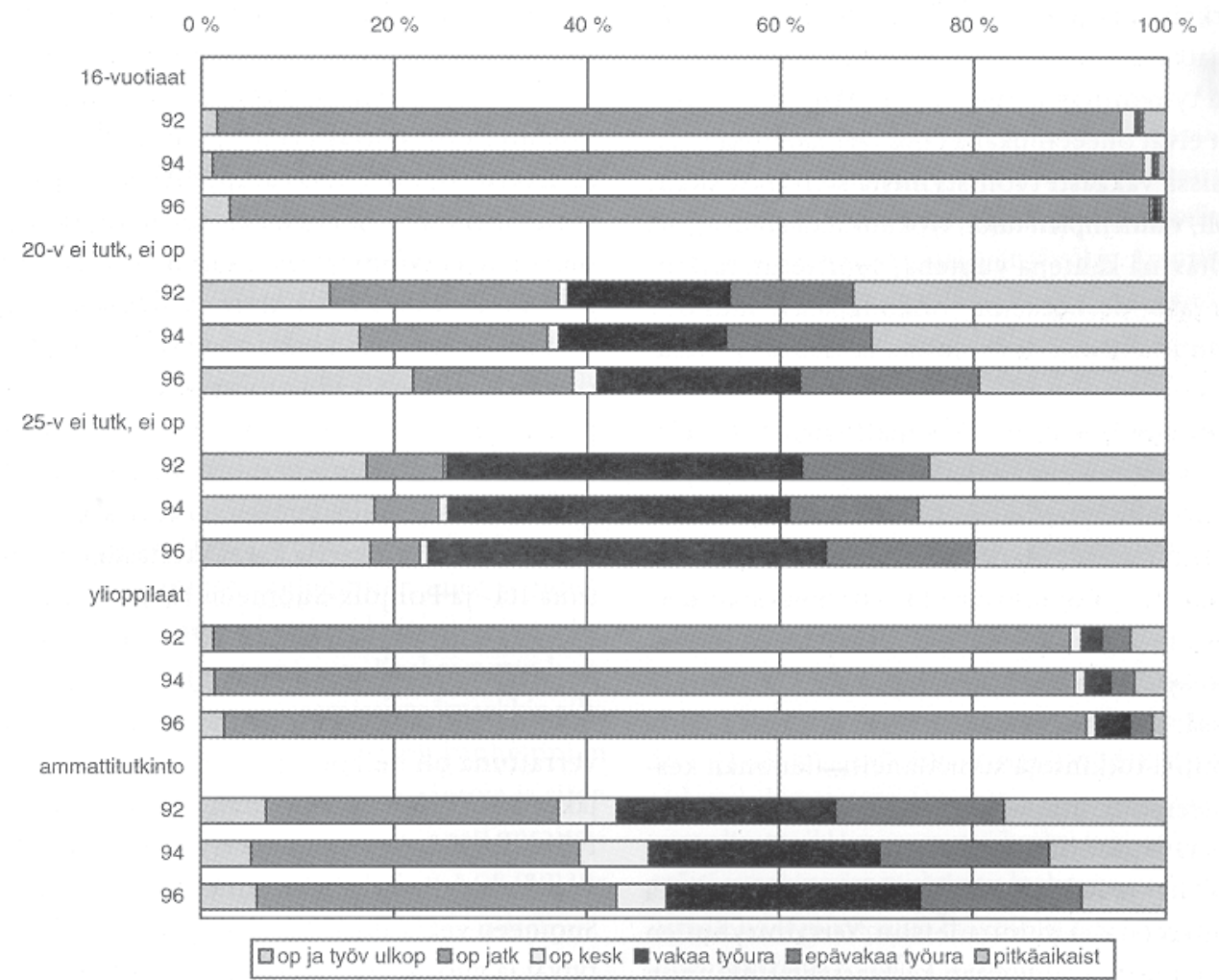


Kuvio 2. Kahden vuoden seurannassa pitkäaikaistyöttömien osuudet eräiden ammatillisen tutkinnon suorittaneista $(\%)$.

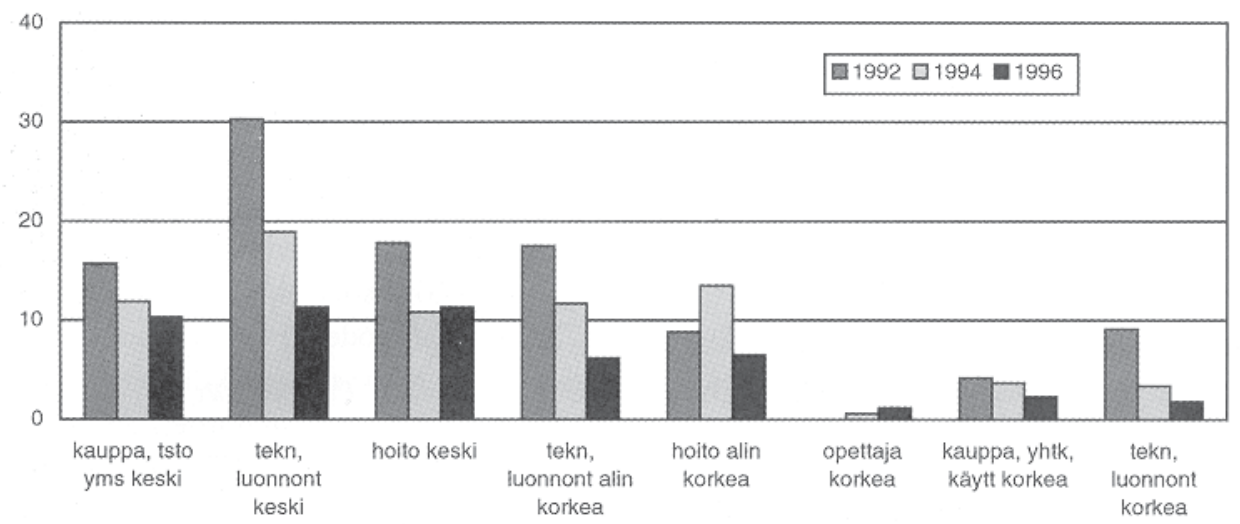

kuin peruskoulun jälkeisten opintojen ulkopuolelle jääneet. Tutkinnon suorittaneiden asema työmarkkinoilla myös parani laman hellittäessä, pelkän peruskoulun varassa työmarkkinoilla olleiden nuorten asemassa myönteiset muutokset olivat huomattavasti pienempiä.

\section{Työmarkkinamenestyksen eväät}

Ammattitutkinnon suorittaneiden menestystä työmarkkinoilla selvitettiin logistisilla regressioanalyyseilla, joissa vakaasti työllistyneitä verrattiin pitkäaikaistyöttömien ja epävakaalle työmarkkinauralle päätyneiden ryhmään. Opiskelua jatkavat, uudet opinnot keskeyttäneet ja pääosin työvoiman ja opintojen ulkopuolelle jääneet eivät olleet mukana tässä tarkastelussa. Analyysissa vakaasti työllistymistä selittävät sukupuoli, vanhempien tulot, työkuukaudet otosvuotta edeltävinä kahtena vuotena, suoritetun tutkinnon taso, perheasema (onko lapsia), suuralue ja muuttaminen otosvuonna tai seuranta-aikana.

Kuviossa 4 on esitetty mallien kerroinsuhteet. Kerroinsuhde (riskisuhde, odds ratio) ilmaisee selittävän muuttujan vaikutuksen vakaasti työllistymisen todennäköisyyteen: jos kerroinsuhde on 1, vaikutusta ei ole ja esimerkiksi kerroinsuhteella 1,5 vakaan työllistymisen todennäköisyys on $50 \%$ korkeampi kuin vertailuryhmässä. Mallissa verrataan miehiä naisiin, korkeampia tutkintoja suorittaneita alemman keskiasteen tutkinnon suorittaneisiin, lapsia hankkineita lapsettomiin, Uuttamaata ja "Väli-Suomea" Itäja Pohjois-Suomen suuralueeseen sekä muuttaneita ei muuttaneisiin. Vertailuryhmien - siis

miesten, alemman keskiasteen tutkinnon suorittaneiden jne. kerroinsuhde on siis 1 ja ne on jätetty pois kuviosta. Vanhempien tuloissa kerroinsuhde ilmaiseen 50000 markan ja työkuukausissa yhden kuukauden lisäyksen vaikutuksen vakaan työllistymisen todennäköisyyteen.

Tilastollisesti merkitseviä ovat kaikki malleihin otetut selittäjät lukuun ottamatta perhetilannetta vuoden 1994 mallissa ja muuttamista vuosien 1994 ja 1996 malleissa.

Lama iski ensin miesvaltaisille aloille, mikä näkyy naisten parempana vakaan työllistymisen todennäköisyytenä vuoden 1992 otoksessa, vuosien 1994 ja 1996 otoksissa miesten menestys taas oli naisia selkeästi parempi. Tutkinnon taso vaikutti hyvin vahvasti ja myös suhteellisen suoraviivaisesti: mitä korkeampi tutkinto, sitä parempi menestys. Ylemmän kandidaattitutkinnon suorittaneet työllistyivät vakaasti vuosien 1992 ja 1996 otoksissa neljä kertaa todennäköisemmin kuin alemman keskiasteen tutkinnon suorittaneet, vuoden 1994 otoksessa ero oli hieman pienempi. Suuralue erotteli myös hyvin tehokkaasti ammattitutkinnon suorittaneita. Uudellamaalla vakaan työllistymisen todennäköisyys oli vuoden 1992 otoksella kaksinkertainen verrattuna Itä- ja Pohjois-Suomeen (Lappi, Kainuu, Pohjois-Karjala) ja vuoden 1996 otoksella todennäköisyys oli peräti kuusinkertainen. Itä- ja Pohjois-Suomen asema myös "Väli-Suomeen" verrattuna oli heikompi ja heikentyi seurantajaksoittain: viimeisenä seurantajaksona vakaalle työuralle pääsyn todennäköisyys oli "Väli-Suomen" alueella kaksinkertainen Itä- ja Pohjois-Suomeen verrattuna. Alueelliset erot siis kärjistyivät ja vuo- 
Kuvio 3. Ammattitutkinnon suorittaneiden vakaasti työllistymiseen vaikuttavat tekijät logistisessa regressioanalyysissa (kerroinsuhteet).

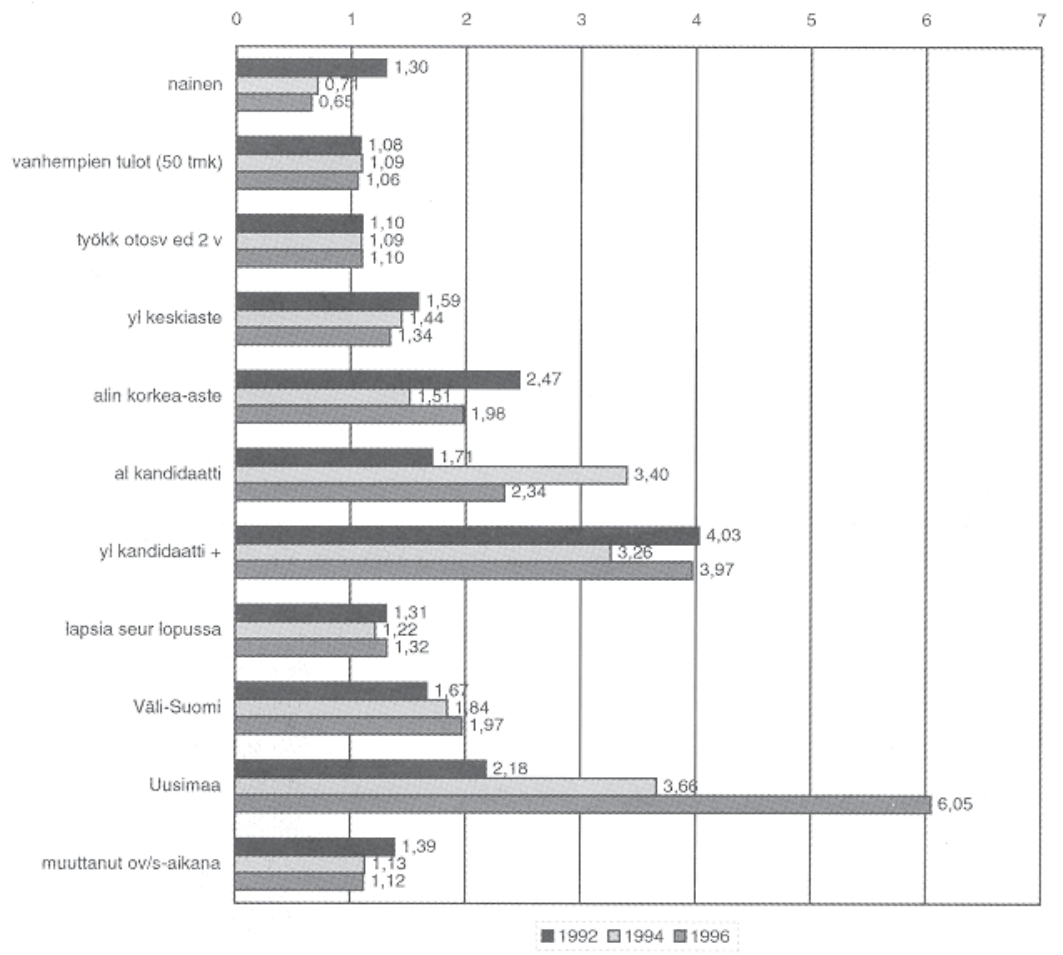

sikymmenen lopulla Uusimaa, keskeisesti pääkaupunkiseudun työssäkäyntialue, oli myös nuorten kannalta muuta maata selkeästi paremman työllisyyden alue. Pääkaupunkiseudun asuntotilanne taas esti normaalia työllisyyseroja tasaavaa muuttoliikettä, joten alueelle muodostui jossain määrin muusta maasta erilliset - ja paremmat - työmarkkinat.

Otosvuotta edeltävä, pääsääntöisesti siis opiskeluaikainen työ paransi selkeästi menestystä valmistumisen jälkeen: jokainen työkuukausi lisäsi vakaan työllistymisen todennäköisyyttä kaikkina seurantajaksoina noin 10 prosenttia. Opiskeluaikainen työ oli siis hyvin kannattavaa. Vanhempien tuloilla oli myös samansuuntainen vaikutus. Selkeämmin vanhempien tulot ja ennen kaikkea koulutus vaikuttivat kuitenkin jo tutkimusryhmiin valikoitumiseen. Korkeammin koulutettujen, paremmissa asemissa työmarkkinoilla olevien ja paremmin ansaitsevien vanhempien lapset suorittivat korkeampia tutkintoja ja siten työllistyivät vakaammin ja oletettavasti ansaitsivat myös muita paremmin. Koulutus on tämänkin selvityksen mukaan periytyvä ominaisuus.

\section{Työ- ja työttömyyshistoria}

20- ja 25-vuotiaiden enintään peruskoulun suorittaneiden uria tarkasteltiin työmarkkinahistorian valossa. Alan tutkimuksissa aiemman työ- ja työttömyyshistorian on todettu olevan erittäin merkittävä työmarkkinoilla menestymistä ennustava tekijä, niin tässäkin. Ammattitutkintoa vailla olevien uraa ennusti hyvin vahvasti aiempi työ ja työttömyys. Paljon työssä olleet pysyivät kaikkina seurantajaksoina hyvin todennäköisesti vakaalla työuralla ja vähiten työssä olleiden oli lähes mahdotonta työllistyä vakaasti. Työttömyyshistorian vaikutus oli samanlainen: eniten työttöminä olleet pysyivät seurannassakin enemmistöltään pitkäaikaistyöttöminä tai epävakaalla työuralla (kuvio 4). 25-vuotiailla määräytyminen oli nuorempaa ikäluokkaa vahvempaa.

Kummankin ikäryhmän paljon työttöminä olleiden pitkäaikaistyöttömyys väheni viimeisenä seurantajaksona. 20-vuotiailla vähenemistä korvasi siirtymä työvoiman ulkopuolelle. Huomattavaa on, että opiskelu-urat olivat kaikkina seurantajaksoina ja kummassakin työttömyyshisto- 
Kuvio 4. 20- ja 25-vuotiaiden urat kahden vuoden seurannassa otosvuoden ja sitä edeltävien kahden vuoden yhteenlaskettujen työttömyyskuukausien mukaan (\%).

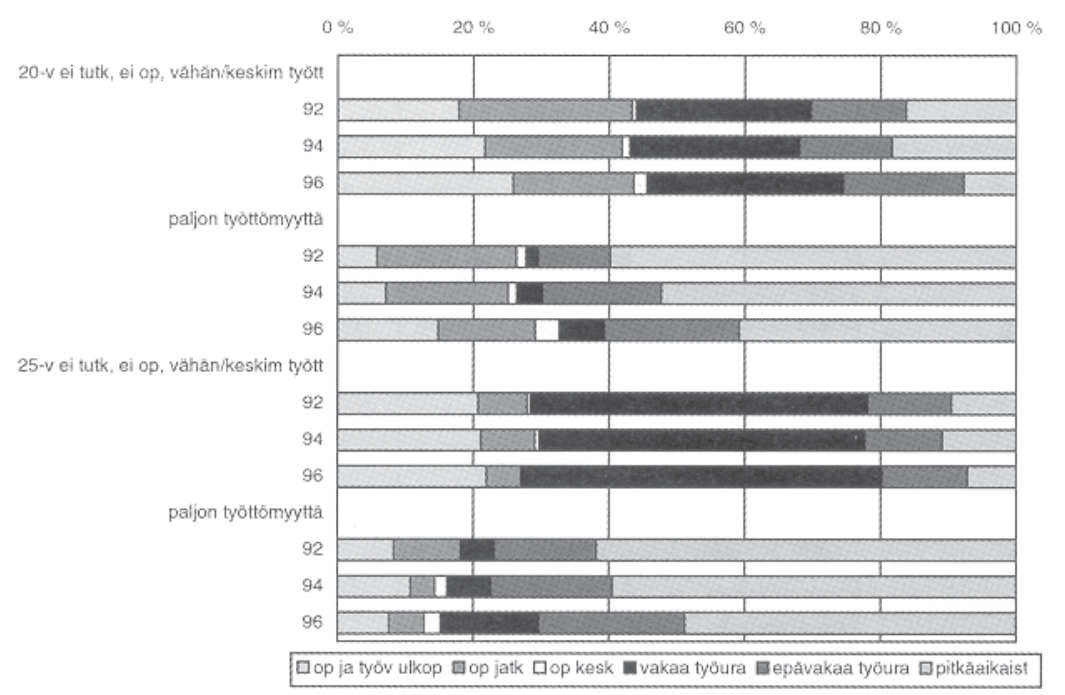

rian mukaisessa luokassa sunnilleen yhtä yleisiä: työttömyys ei siis lisännyt näiden tutkimusryhmien opiskelua.

\section{Opinnot keskeyttäneet}

Opintojen keskeyttämistä tarkasteltiin otosvuotta seuraavien neljän vuoden urien perusteella. Opinnot keskeyttäneiksi katsottiin ne, jotka neljän vuoden seuranta-aikana tutkintoa suorittamatta opiskelivat ensimmäisenä ja/tai toisena vuonna mutta eivät enää kahtena viimeisenä. Opintojen keskeyttäminen ja jossakin toisessa koulutuksessa jatkaminen ei luokittele otoshenkilöä keskeyttäneeksi: oleellista on kahden viimeisen seurantavuoden opiskelemattomuus. Opinnot keskeyttäneitä tarkasteltiin siten, että otosvuoden jälkeisenä neljän vuoden seurantajaksona keskeyttäneille muodostettiin kahdelle viimeiselle vuodelle samanlainen uramuuttuja kuin kaksivuotisseurannassakin. Koska miesten ja naisten urat poikkesivat toisistaan, tarkastelut tehtiin sukupuolittain. Vuoden 1992 otoksessa opinnot vuosien 1993-96 nelivuotisseurannassa keskeyttäneitä seurattiin siis vuosina 1995-96 ja vuoden 1994 otoksen keskeyttäneitä vastaavasti vuosina 1997-98. Viimeisen, vuoden 1996 otoksen keskeyttäneiden toimintaa ei voitu selvittää, koska tietoja vuosilta 1999-2000 ei ollut käytettävissä.

Opinnot keskeyttäneitä oli lähinnä ammattitutkinnon otosvuonna suorittaneiden ja 16vuotiaiden ryhmissä. 16-vuotiaista keskeytti hyvin pieni osa, kummastakin - siis vuosien 1992 ja 1994 - otoksesta noin kolme prosenttia, henkilöinä tämä on noin 170 ja väestöön suhteutettuna noin 2000 henkilöä. Vuoden 1996 otoksessa opintojen keskeyttäminen väheni tästäkin. Otosvuonna ammattitutkinnon suorittaneista neljän vuoden seurannassa opinnot keskeyttäneitä oli vuosien 1992 ja 1994 otoksista 8 ja 10 prosenttia.

Ammattitutkinnon suorittaneiden ja 16-vuotiaiden opinnot keskeyttäneiden seurantajakson urat poikkesivat selkeästi toisistaan (kuvio 5). Ammattitutkinnon suorittaneet työllistyivät suhteellisen hyvin: kumpanakin seurantajaksona miehistä yli puolet ja naisistakin vajaa puolet oli vakaalla työuralla ja pitkäaikaistyöttömyys oli suhteellisen vähäistä. Ilmeisesti ammattitutkinnon suorittaneet olivat huonossa työllisyystilanteessa aloittaneet opiskelun uutta tutkintoa varten ja opinnot keskeytettiin kun työtä löytyi. Ammattitutkinnon suorittaneiden opintojen keskeyttäminen ei siis aiheuttanut ongelmia työelämässä.

16-vuotiaiden opinnot keskeyttäneiden urat olivat tyystin toisenlaiset. Vain 10-30 prosent- 
Kuvio 5. Opinnot keskeyttäneiden nelivuotisseurannan kahden viimeisen vuoden urat sukupuolen mukaan $(\%)$.

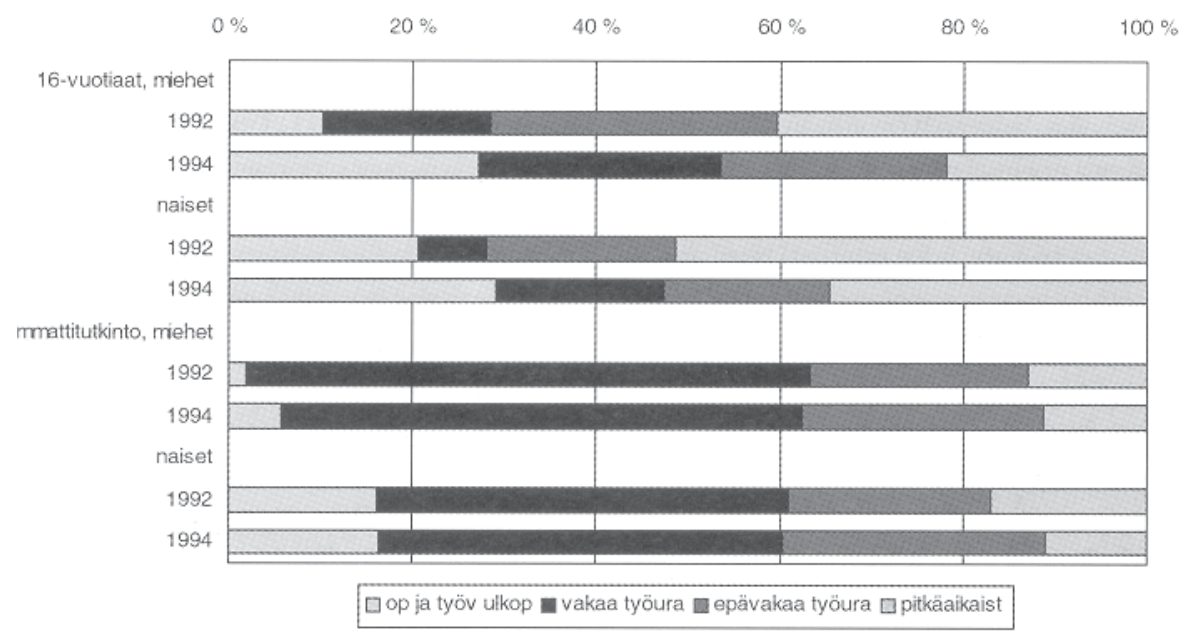

tia näistä oli työllistynyt vakaasti ja pitkäaikaistyöttömyys oli huomattavan yleistä, joskin se väheni vuoden 1994 otoksessa. Toisaalta työvoiman ulkopuolisuus yleistyi. Tähän vaikutti ilmeisesti se, että vuodesta 1996 alle 20-vuotiaat vailla ammattitutkintoa olevat työttömät, jotka eivät pyrkineet riittävästi opiskelemaan, menettivät työmarkkinatukioikeuden. Työttömänä työnhakijana ei siis enää päivärahankaan vuoksi kannattanut olla. Sukupuoliero ilmeni siten, että naisilla työvoiman ulkopuolisuuteen liittyivät yleisesti lapset ja oma perhe kun miehet olivat enemmistöltään vielä vanhempiensa luona asuvia.

Otosvuonna 16-vuotiaiden opintojen keskeyttäminen oli tietenkin yksi tie tutkimuksessa tarkasteltuihin 20- ja 25-vuotiaiden enintään peruskoulun suorittaneiden ja opintojen ulkopuolelle jääneiden ryhmiin ja heidän menestyksensä työmarkkinoilla selittyy suurelta osin samojen tekijöiden - työ- ja työttömyyshistorian - perusteella kuin näidenkin. Ilman ammattitutkintoa ja heikon työhistorian pohjalta oli hyvin vaikea päästä vakaalle työuralle. Näille opinnot keskeyttäneille ei siten voida ennustaa hyvää menestystä tulevaisuudenkaan työmarkkinoilla.

\section{Yleissivistävästä koulusta työelämään}

Nuoret tulivat työmarkkinoille valtaosaltaan am- mattitutkinnon suoritettuaan ja pieni osa myös keskeytettyään ilman tutkintoa peruskoulun jälkeiset opinnot. Jonkin verran nuoria tuli työmarkkinoille myös suoraan yleissivistävästä koulusta, siis peruskoulun tai lukion suoritettuaan. Kaksivuotisseurannassa vuoden 1992 otoksen 16-vuotiaista päätyi kolme ja ylioppilaista yhdeksän prosenttia työmarkkinaurille. Osuudet pienenivät 1990 luvun edetessä ja vuoden 1996 otoksen 16-vuotiaista enää prosentti ja ylioppilaista seitsemän prosenttia sijoittuivat näihin luokkiin.

Pienen 16-vuotiaiden työelämään tulevien ryhmän menestys työmarkkinoilla oli heikko, joskin se parani viimeistä seurantajaksoa kohti. Tuolloin kuitenkin edelleen lähes puolet ryhmästä oli pitkäaikaistyöttömänä ja vain alle kolmasosa oli päässyt vakaalle työuralle. Ylioppilaat menestyivät huomattavasti paremmin: vuoden 1992 otoksen työelämään tulevista neljäsosa oli vakaalla työuralla kun vuoden 1996 otoksesta vastaava osuus oli jo puolet. Työurat paranivat siis selkeästi ja vuoden 1996 otoksen ylioppilaat menestyivät työurilla mitaten yhtä hyvin kuin ammattitutkinnon suorittaneet.

Ylioppilaista miehet tulivat naisia useammin työmarkkinoille, samoin uusimaalaiset muita useammin. Miehet ja Uudenmaan ylioppilaat myös menestyivät muita paremmin työmarkkinoilla. Paranevan - ja Uudellamaalla viimeisenä seurantajaksona jo suhteellisen hyvän - työllisyyden 
oloissa ylioppilastutkinnon antamilla valmiuksilla työllistymisen mahdollisuudet olivat jo kohtuullisen hyvät. Ylioppilaiden tulo työmarkkinoille lisääntyi siellä missä kysyntää oli riittävästi.

\section{Pääosin työvoiman ja opintojen ulkopuolelle jääneet}

Seurantamuuttujan pääosin työvoiman ja opintojen ulkopuolelle jääneiden luokka määriteltiin siten, että otoshenkilö ei opiskellut ja kuului alle 12 kuukautta työvoimaan kahden vuoden seuranta-aikana. Uratarkasteluissa havaittiin tämän luokan kasvaneen selkeimmin 20-vuotiaiden opintojen ulkopuolelle jääneiden keskuudessa. Tämä tutkimusryhmä oli kuitenkin pieni ja pieneni vuosikymmenen edetessä.

Ammattitutkinnon suorittaneista selvästi alle kymmenen prosenttia kuului tähän luokkaan eikä sen osuus muuttunut otoksesta toiseen. Ammattitutkinnon suorittaneiden pääosin työvoiman ja opintojen ulkopuolisten luokkaan kuuluvista miehistä puolet suoritti asevelvollisuuttaan seuranta-aikana. Luokan naisista $70-80$ prosentilla oli taas seurannan lopussa lapsia. Toisen seurantavuoden lopussa noin puolet ryhmän miehistä oli palanneen työvoimaan ja ainoastaan 20-30 prosentia miehistä oli edelleen "ilman perusteltua syytä" työvoiman ulkopuolella.

Otosvuonna 16-vuotiaiden ryhmästä pieni, joskin viimeisenä otosvuonna noin kolmeen prosenttiin kasvanut osuus kuului opiskelemattomien ja pääosin työvoiman ulkopuolisten luokkaan. Seurantajakson lopussa ryhmän miehistä oli ensimmäisenä seurantajaksona kaksi kolmasosaa palannut työvoimaan tai muuten perustellusti työvoiman ulkopuolella mutta viimeisenä jaksona enää alle puolet. Myös 20-vuotiaiden ryhmässä havaittiin miehillä vastaava kasvu viimeisenä seurantajaksona. 16-vuotiaiden naisten opintojen ja pääosin työvoiman ulkopuolisten luokka kasvoi myös, mutta samanlaista selkeää "perusteettoman" työvoiman ulkopuolisuuden kasvua kuin miehillä ei havaittu. Väestöön suhteutettuna tämä ryhmä kasvoi 16-vuotiaiden tutkimusryhmässä ensimmäisen seurantajakson lopusta viimeisen seurantajakson loppuun, siis vuosien 1998/99 vaihteeseen kolminkertaiseksi, noin tuhanteen henkeen.
Sekä 20-vuotiaiden että 16-vuotiaiden opintojen ja työvoiman ulkopuolisuuden kasvun taustalla oli ainakin osittain vuosina 1996-97 toteutetut työmarkkinatukiehtojen kiristykset. Työttömiä ja ammattitutkintoa vailla olevia nuoria patisteltiin opintojen pariin työmarkkinatuen menetyksen uhalla ja samalla lisättiin opiskelupaikkoja. Peruskoulun jälkeisten opintojen kasvu alkoi kuitenkin jo vuosina 1992-94 eli nuoriso reagoi työmahdollisuuksien nopeaan heikkenemiseen opiskelulla. Epäilemättä työmarkkinatukiuudistuksillakin oli samansuuntainen vaikutus, etenkin kun työvoimaviranomaiset panostivat muutenkin nuoriin mm. työvoimapoliittisia toimia lisäämällä. Kääntöpuolena tälle oli se, että pieni ryhmä nuorista siirtyi työttömyydestä mieluummin työvoiman ulkopuolelle kuin opintoihin.

\section{Lopuksi}

Verrattuna edeltävään nousukauteen nuorten työmarkkinat olivat 1990-luvulla selkeästi heikommat. 1980-90 -lukujen vaihteessa työttömyys oli hyvin vähäistä ja vakaat työurat yleisiä. Pienelle työttömien joukolle velvoitetyöllistäminen ja sillä uudistettava ansiosidonnainen työttömyysturva tuottivat kohtuullisen toimeentulon. Laman alkaessa nuorten työttömyys nousi ensin hyvin jyrkästi mutta alkoi laskea jo aiemmin kuin kokonaistyöttömyys. 1990-luvun lopulla keskeiseksi työttömyysongelmaksi nousi vanhempien ikäryhmien pitkäaikais- ja toistuvaistyöttömyys.

Nuorisotyöttömyyttä alensi sekä lisääntynyt opiskelu että paraneva työllisyys. Tässä tutkimuksessa havaittiin ainoastaan joidenkin vuonna 1992 valmistuneiden ryhmien päätyneen laajemmin pitkäaikaistyöttömiksi. 1992 valmistuneiden seuranta osui laman syvimpiin vuosiin eikä vastaavaa ilmennyt enää myöhemmissä otoksissa. 1990-luvun myötä paranevilla nuorten työmarkkinoilla oli vakaa työllistyminen kuitenkin edeltävää nousukautta epävarmempaa ja riski työttömyydestä jatkuvasti läsnä. Työttömyydeltä suojasi suhteellisen varmasti vasta riittävän korkea tutkinto. Näin ollen on hyvin ymmärrettävää, että alemman ammattitutkinnon suorittaneista useimmat jatkoivat opintojaan. Vaikka työmark- 
kinat paranivat, ne eivät kuitenkaan parantuneet riittävästi. Toipuminen laman pohjasta ei myöskään ollut yhtäläistä kaikille: tarkastelujaksolla miesvaltaisten tekniikan alojen - joiden lähtötasokin tosin oli heikko - työmarkkinat paranivat nopeimmin, samoin Uusimaa erottui yhä selvemmin paremman työllisyyden alueeksi.

Opiskelu yleistyi erityisesti vuosina 199294 ja pysyi saavutetulla tasolla vuosikymmenen loppupuolen. Opiskelun yleistymistä indikoi myös tarkasteltujen 20- ja 25-vuotiaiden peruskoulupohjalla työmarkkinoilla olleiden ryhmien pieneneminen. Näihin jäivät nuoret, joiden opiskeluaktiivisuus oli vähäisintä ja joiden opiskelua ei lisäännyt edes heikko menestys työmarkkinoilla. Ammattitutkintoa vailla olevien heikkoina pysyneet työurat osoittavat, että ilman tutkintoa tai riittävää työkokemusta menestystä työmarkkinoilla ei ollut odotettavissa. Laman aikana työkokemuksen hankkiminen oli tietenkin vaikeaa eikä paranevassa työllisyystilanteessakaan ollut enää entisen lailla kysyntää ammattitaidottomalle työvoimalle.

1990-luvulla työttömyysturvaa heikennettiin: velvoitetyöllistäminen lopetettiin, ansiosidonnaisen työttömyysturvan saamisen työssäoloehtoa pidennettiin ja nuorten työmarkkinatuen saamisehtoja kiristettiin. Julkisen sektorin palkkaperusteisen tukityön sijaan vallitsevaksi nuorten työvoimapoliittiseksi tukityömuodoksi nousi työharjoittelu työmarkkinatuella. Työttömyysturvan taso siis laski ja sen saaminen hankaloitui. Erityisesti kritikoitiin vuosien 199697 työmarkkinatukiuudistusta, jonka mukaan ammattitutkintoa vailla olevien nuorten oli pyrittävä opiskelemaan saadakseen työmarkkinatukea. Opiskelupaikkoja hakemattomat nuoret menettivät työmarkkinatukioikeutensa, mitä pidettiin jonkinlaisena kansalaisoikeuksien loukkauksena. Samalla kuitenkin nuorten opiskelumahdollisuuksia parannettiin lisäämällä opiskelupaikkoja.

Nuorten opiskelu oli kuitenkin jo ennen näitä toimia yleistynyt: työnsaantimahdollisuuksien heiketessä koulun penkki tuntui entistä houkuttelevammalta. Työmarkkinatuen saamisehtojen kiristämisen seurauksena ainoastaan hyvin pieni osa nuorista jäi opiskelun ja sen myötä myös työvoiman ulkopuolelle. Suurimmalle osalle "työttömyysura" ei ollut "opiskelu-uran" realistinen vaihtoehto, olipa työttömyysturva millainen tahansa.

Nuorten työmarkkinat olivat 1990-luvun lopullakin heikommat ja työllistyminen epävarmempaa kuin edeltävällä nousukaudella. Toisaalta laman seurauksena nuoret ovat aiempaa paremmin koulutettuja, ja tälle hyvin koulutetulle työvoimalle on tulevaisuudessakin kysyntää.

\section{Viite}

1 Katsaus perustuu Simo Ahon ja Hannu Koposen tekemään tutkimukseen Nuorten opiskelu- ja työurat 1990-luvulla. Nuorisoasiain neuvottelukunta, Nuora, Julkaisuja 20, 2001.

Tutkimuksessa käytettiin Tilastokeskuksessa muodostettua 350000 henkilön satunnaisotosta vuoden 1997 lopun väestöstä. Tutkimusryhmiksi poimittiin vuosilta 1992, 1994 ja 1996 seuraavat ryhmät:

1. 16-vuotiaat, pääsääntöisesti siis peruskoulun otosvuonna päättäneet.

2. 20-vuotiaat, jotka eivät opiskelleet otosvuonna ja joilla ei ollut peruskoulun jälkeistä tutkintoa.

3. Vastaavat 25-vuotiaat

4. Ylioppilastutkinnon otosvuonna suorittaneet.

5. Ammattitutkinnon otosvuonna suorittaneet.

Vuosittain tutkimusryhmiin kuului yhteensä noin 14500 henkeä, näistä 16-vuotiaita 5500 .

Tutkimusryhmiä seurattiin pääsääntöisesti otosvuotta seuraavat kaksi vuotta, vuoden 1992 ryhmiä siis vuodet 1993-94 jne. Kaksivuotiskausille muodostettiin uramuuttuja kuvaamaan otoshenkilön näiden kahden vuoden "pääasiallista toimintaa". Uramuuttujan luokat ovat seuraavat:

1. Opintoja jatkavat

2. Opinnot keskeyttäneet

3. Vakaasti työllistyneet

4. Epävakaalle työuralle joutuneet

5. Pitkäaikaistyöttömät

6. Pääosin työvoiman ja opintojen ulkopuolella olevat

Luokittelussa opiskelu syrjäyttää työurat eikä seuranta-aikana opiskelleiden työssäkäyntiin siten kiinnitetä huomiota. Opintoja jatkavat opiskelivat toisena seurantavuonna tai suorittivat tutkinnon seuranta-aikana. Opinnot keskeyttäneiksi katsotaan (ilman tutkinnon suorittamista) vain ensimmäisenä seurantavuonna opiskelleet. Luokkien 3-5 työurat eivät sisällä opiskelua ja edellyttävät seuranta-aikana vähintään 12 kuukauden työvoimaan kuulumista, siis työssä, työttömänä tai työvoimapoliittisissa toimissa oloa. Vakaasti työllistyneet olivat työssä avoimilla työmarkkinoilla (ei työvoimapoliittisessa tukityössä) vähintään $80 \%$, epävakaalla työuralla 20-80\% ja pitkäaikaistyöttömät alle $20 \%$ työvoimaan kuulumisajastaan. Pääosin työvoiman ja opintojen ulkopuolella olevat eivät opiskelleet ja kuuluivat työvoimaan alle vuoden kahden vuoden seurantajaksona. 